\title{
Identification of landslide susceptibility zonation in CNG ghat section, Gudalur, The Nilgiris - Using GIS based ANN/Multi criteria method
}

\author{
Prasanna Venkatesh, $\mathrm{S}^{2, *}$, Saranaathan, S.E. ${ }^{1}$ \\ ${ }^{1}$ School of Civil Engineering, SASTRA University, Thanjavur, Tamil Nadu. \\ ${ }^{2}$ School of Earth \& Atmospheric Science, University of Madras, Chennai, Tamil Nadu - esaranathan@ yahoo.co.in
}

Commission V, SS: Disaster Monitoring, Damage Assessment and Risk Reduction

Key words: Remote Sensing, Multi-criteria analysis, Landslide Susceptibility Zones.

\begin{abstract}
:
Among the various natural hazards, landslide is the most widespread and damaging hazard. In recent times, throughout a lot of attention is being drawn to evaluate the risk due to landslides. The invention of remote sensing and GIS have been new vistas in the field of geo scientific studies viz. geomorphological mapping, groundwater potential mapping, disaster management etc. The present study has been undertaken to study different thematic maps like, contour, drainage, slope, aspect, curvature, DEM, DTM, drainage density, drainage intensity, geology, lineament, lineament density, lineament intensity, geomorphology, land use, weathering thickness, run off, soil thickness and buffer maps like road, drainage, lineament etc. in CNG ghat section, Gudalur, The Nilgiris. For this purpose, the satellite image IRS - RS2, LISS III January 2014 used to prepare different thematic maps. The contour, drainage and road network were incorporate from SoI Toposheets. The slope, curvature, aspects and buffer maps were prepared from GIS environments. Based on field studies, above said thematic maps (22 nos.) were prepared and were grouped into 3 categories viz. Geology, Hydrology and Terrain. In each category the input maps were assigned different score as well as each layer has been given different weightage. Finally the categories are analysed through multi - criteria analysis to find out 5 different vulnerability classes. The 5 different land susceptibility zones are classified as very low, low, moderate, high and very high. The percentages of area under different susceptibility classes are 3\%,20\%,51\%, 25\%, and $1 \%$ respectively. The locations of small area major landslides and slip locations were calculated from different years using (2010 and 2014) Trimble GPS in the field. The field data was converted into point layer in GIS and landslide inventory map was prepared. This map was superimposed in landslide susceptibility zonation map. As per field data $0 \%, 9.25 \%, 57.5 \%, 32 \%$ and $1.25 \%$ Slide points are come under very low, low, moderate, high, very high susceptibility zones respectively.
\end{abstract}

\section{INTRODUCTION}

\subsection{Introduction}

Landslides and other mass movements are common phenomenon in the hilly region. The general introduction of the landslides, the various types of landslides and causes of landslides are deeply discussed by Varnes (1978). Landslide in Nadugani area occur during heavy rainfall - the Devala is received highest rainfall in South India and it is also called Cherrapunji in South India - resulting the loss of natural vegetation, loss of tea plantation, damage in road network. Several factors affect the stability of the slopes \& in this paper, the geological factors such as geology, weathering thickness, lineament, lineament density, lineament intensity, lineament buffer, and hydrological factors like drainage, drainage buffer, drainage density, drainage intensity, run-off, and terrain factors like contour, slope, slope aspects, geomorphology, structure, soil, land use, etc. There are numerous approaches for hazard zonation mapping. The study area landslide types are mapped by large scale spatial data, pale scars and field survey, classified and landslide distribution in GIS environment. The use of GIS in the modelling of landslide hazard using many different parameters maps was attempted by several researchers (Reza Talaei, 2014; Nagarajan et al 1998; Sriramkumar et al 2006; Kannan et al 2011; Saranathan et al 2012; Kannan et al 2015; Saranaathan and Mani 2016; Mani and Saranaathan 2016).

The present study has been attempted for the identification of spatial distribution of potential slope instability in a representative hill slope over which the attributes of geological factors, hydrological factors and terrain factors.

\subsection{Study area}

The study area is CNG - 37 ghat road section and its connecting Gudalur and Calicut via Nilampur. It is situated in Nadugani, Gudalur Taluk, The Nilgiris. The study area is enclosed between $11^{\circ} 30^{\prime} \mathrm{N}$ to $76^{\circ} 15^{\prime} \mathrm{N}$ latitudes and $76^{\circ} 30^{\prime} \mathrm{E}$ to $11^{\circ} 15^{\prime} \mathrm{E}$ longitudes. It is covering an area of $4.79 \mathrm{~km}^{2}$ Figure 1 . The elevation varies between $280 \mathrm{~m}$ to $1042 \mathrm{~m}$ above mean sea level. This area is experience highest rainfall next to cherrapunji in India. The measured rainfall varies from $1368 \mathrm{~mm}$ to $2550 \mathrm{~mm}$ per year. In this section most of the area is covered by Hornblend biotite gneiss and small portion occupied by charnockites. The rocks are fissile in nature. The terrain slope is varies from $45^{\circ}$ to $60^{\circ}$. Most of the cover by Tea plantation and southeastern side dense forest are noticed.

\subsection{Data products}

The following spatial data has been used for the study.

- Topo sheets No. 58A/7 (1:50,000) and 58A/7-NE $(1: 25,000)$

- IRS RS2 LISS - IV Geocoded January 2014

- Rainfall data from Taluk office. 


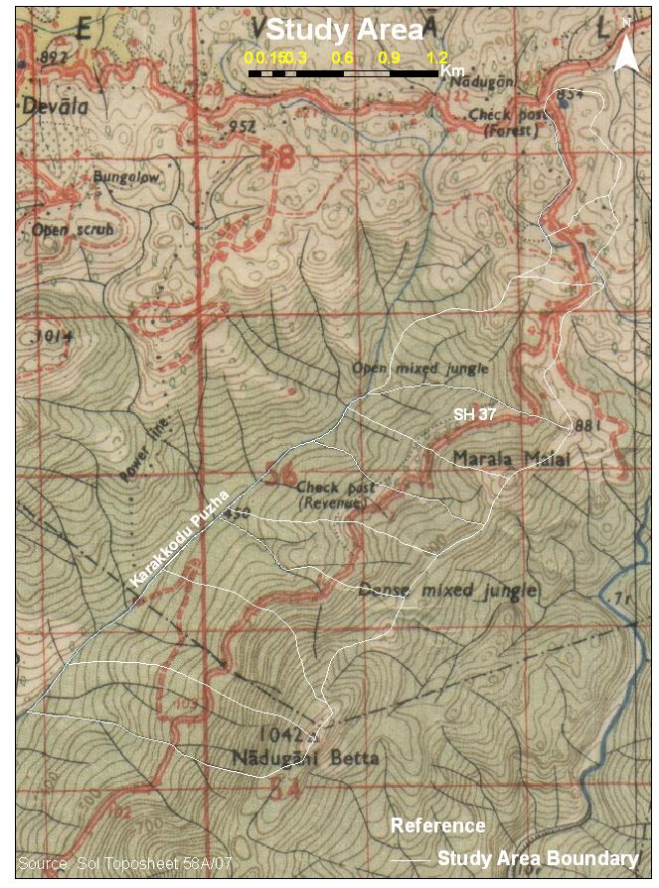

Figure 1 Study area map

\section{METHODOLOGY}

The different thematics maps were prepared in various methods. It is given below:

- The themes like Drainage map, Contour map, and road were derived from SOI Toposheets.

- Soil and soil thickness maps were prepared from field data.

- The Land use, geomorphology and lineament maps are interpreted visually from satellite imagery.

- Slope, slope aspect, drainage density, drainage buffer, and drainage intensity were prepared from relief and drainage maps respectively.

- Lineament density, buffer and intensity maps were prepared from lineament map.

- Using empirical formula for Tamil Nadu hills $\mathrm{Q}=\mathrm{CM}^{2 / 3}$ (Anon 1998), Run-off map was prepared.

- The above prepared maps were geo-referenced and digitized using ARC GIS software.

- Buffer zones were created for drainage map using ARC GIS software.

- The themes have been assigned with proper weightages and scores.

- Multi-criteria analysis of the weighted themes was carried out with Overlay analysis in ARCGIS software to predict landslide vulnerable zones.

The different methodologies adopted for different factors in the present study are explained with the help of different flow charts. Multi-criteria analysis of the weighted themes was carried out with Overlay analysis in ARCGIS software to predict landslide vulnerable zones for hydrological factor (Figure 2). Geological factor analysis, eight thematic layers (Figure 3) was prepared and the map classes occurring on each input map were assigned different scores, as well as maps themselves receiving different weight as before. It is convenient to define the scores in an attribute table for each input map. Third step, important terrain causative factors like, land use, lithology, geomorphology, and structural maps were prepared from high resolution satellite data IRS-RS2 L-IV Feb 2014. In this study, Analytical Hierarchy process method was used to find out susceptibility zonation. Analytical Hierarchy Process is a semi quantitative method, which includes a pair-wise comparison of various landslide-triggering factors to determine prioritized factors weight. Factors weight for all thematic maps was estimated by developing pair-wise comparison matrix as developed by Saaty $(1990,1994)$ and Saaty and Varegas (2001). The detailed methodology of landslide susceptibility zonation has been shown in Figure 4. An artificial neural network is a "computational mechanism able to acquire, represent, and compute a mapping from one multivariate space of information to another, given a set of data representing that mapping" (Garrett 1994). The backpropagation training algorithm is the most frequently used neural networks method (Lee et al. 2004; Sonmez et al. 2006; Tunusluoglu et al. 2007; Zorlu et al. 2008; Nefeslioglu et al. 2008) and is the method used in this study.

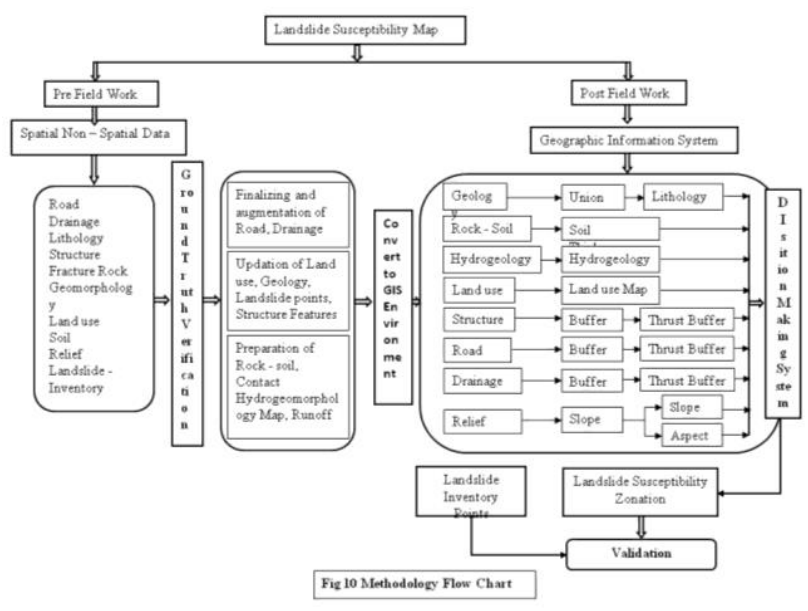

Figure 4 Terrain Flow Chart

\section{RESULT AND DISCUSSION}

The hydrological factorial output landslide vulnerable map is shown in Figure 5. It is found from the output map that the vulnerable zones identified are proportional to the hydrological factors. It classifies the vulnerable zones into very high, high, moderate, low and very low based on the weightage and scores assigned to the different themes. The areas such nadugani betta, marala malai, Nadugani and Kil nadugani comes under high vulnerable zones. These areas have very steep slopes and low drainage density. The output map shows that the very high zones are very limited and occupies about $0.96 \%$ and high hazard zones occupies $29.44 \%$. As per hydrological factors influence the moderate vulnerable zones occupies $55.80 \%$. Low and very low occupies zones about $13.30 \%, 0.50 \%$.

The geological factorial maps are converted into GIS environment and converted into quad tree raster maps. Using multi-creation analysis, weightages are assigned to each thematic layer. Weightage of each theme was provided depending on the severity of the theme related to landslide susceptibility. The scores are assigned to each classes present 
in thematic layers. Higher score for a class, more the susceptibility to landslide compared to others. Based on the multi-creation analysis, the study area is classified into five landslide susceptibility zones (Figure 6). In the study area, very high and the high classes are characterized by tea plantation area indicating the influence of manmade activities. In southern portion the high and very high hazard classes are characterized by thick forest with high degree of slopes (more than $50^{\circ}$ ). The general slope of the area is NW direction, but the micro slopes are facing $\mathrm{SW}$ showing a greater to potential landside susceptibility.

Natural terrain factors play a vital role of occurrence of landslide in $\mathrm{CNG}$ ghat section. CNG ghat section covers $18.5 \mathrm{~km}$ stretch in Nadugani Betta Range. This ridge is controlled by two major fault systems in eastern (Punna puzha) and western (Karakkodu puzha) side. The major lineaments are parallel to Eastern ghat Orogency (Anbazhagan and Saranathan, 2001). In Nadugani betta western slope, some places are steep and very steep in nature compared to the eastern slope. The rocks are steep and fissile in character. In rainy days, water enters into the fissures and debris becomes unstable. It generates slope instability in this ghat section. The study indicates that the ghat section occurred $22.6 \%$ of very high zone, $52.52 \%$ of high zone, $2.55 \%$ of moderate zone and $22.32 \%$ of low zones (Figure 7). The map also is used as basic data for further developmental activities like road widening etc. in this area.

Based on hydrological factors, geological factors and terrain factors maps were assigned different score and as well as each layers has been given different weightage. Finally five different land susceptibility zones are classified as very low, low, moderate, high and very high (Figure 7). The percentages of area under different susceptibility classes are $3 \%, 20 \%, 51 \%, 25 \%$, and $1 \%$ respectively. This map was superimposed in landslide inventory map. As per field data $0 \%, 9,25 \% 57.5 \%, 32 \%$ and $1.25 \%$ slide points are come under very low, low, moderate, high, very high susceptibility zones respectively.

\section{ACKNOWLEDGEMENTS}

The authors thank Prof. R. Sethuraman, Vice-Chancellor of SASTRA University, Thanjavur for having given us facilities to carry out this work. Dr. Bhoop Singh, Head, NRDMS division, Department of Science \& Technology, New Delhi for the financial support for research project entitled "Geoenvironmental factors Assessment and Slope Stability Analysis on $6.5 \mathrm{~km}$ Ghats section from 103/6 to 109/8 km stone on SH 37, Nadugani, Gudalur, The Nilgiris" and encouragement provided to undertake this work

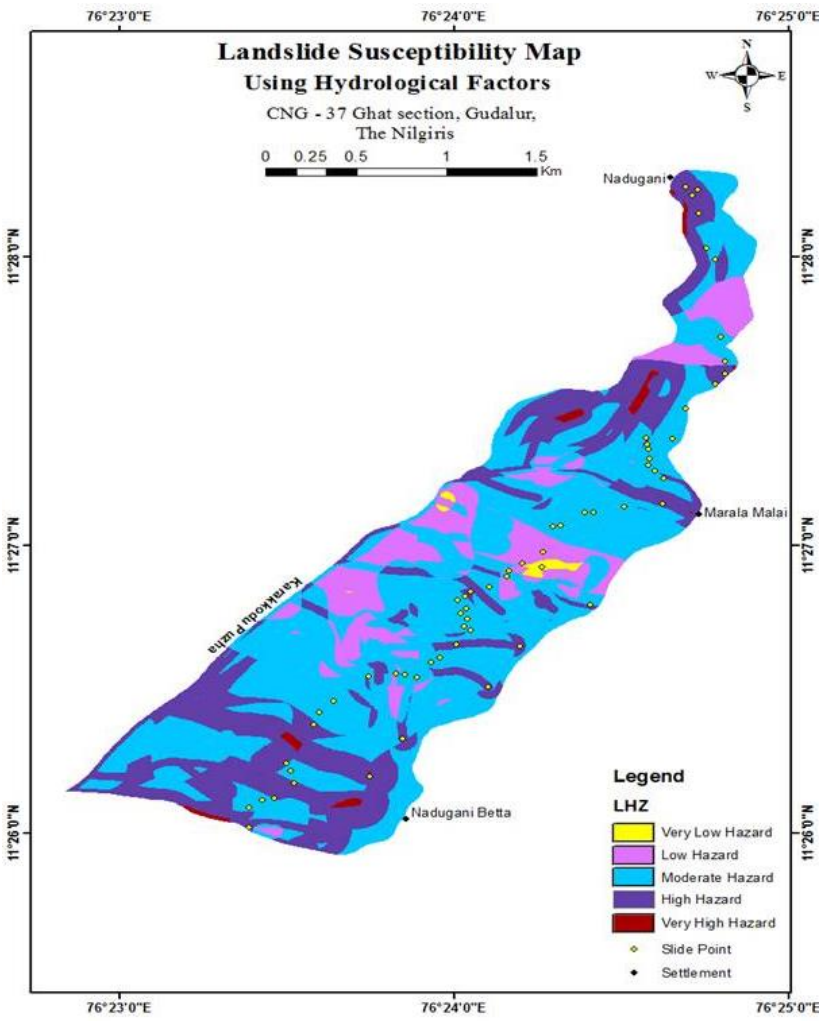

Figure 5 LSZ map using hydrological factors

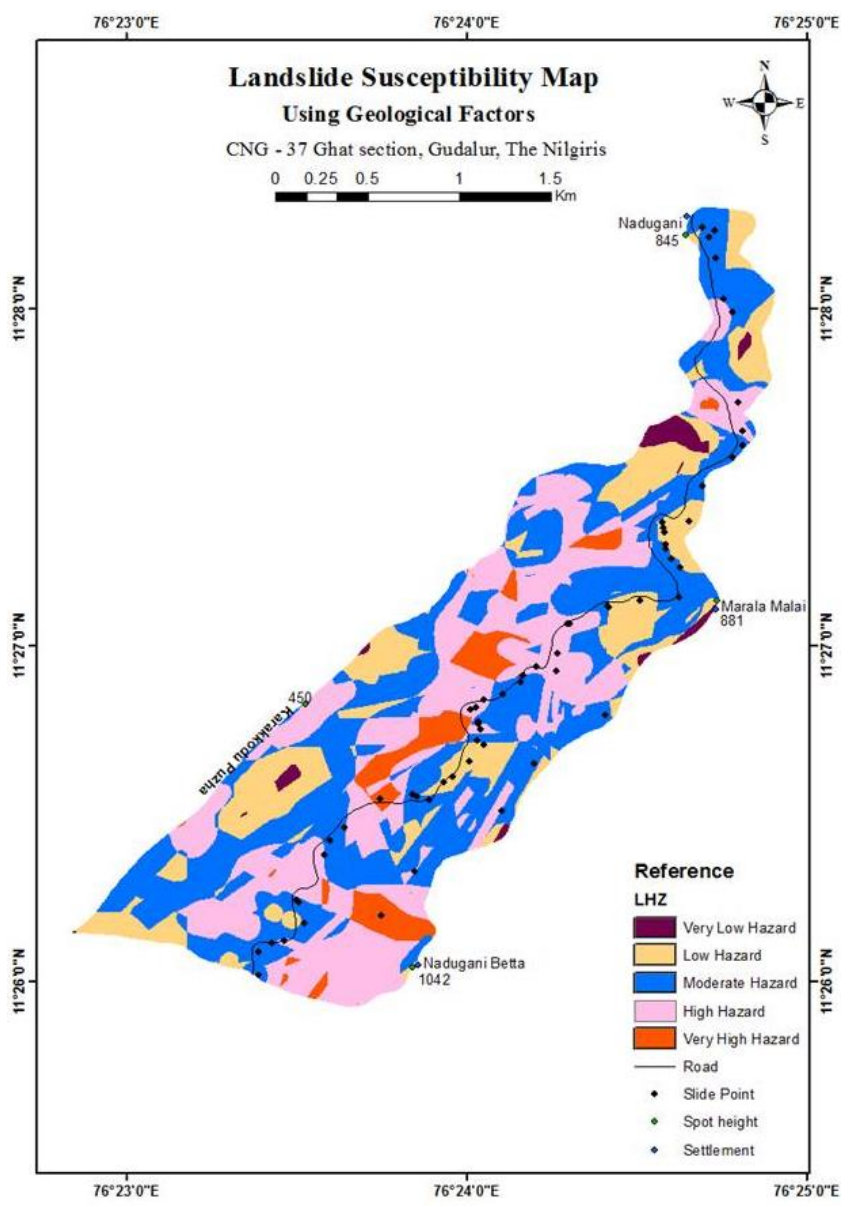

Figure 6 LSZ map using geological factors 


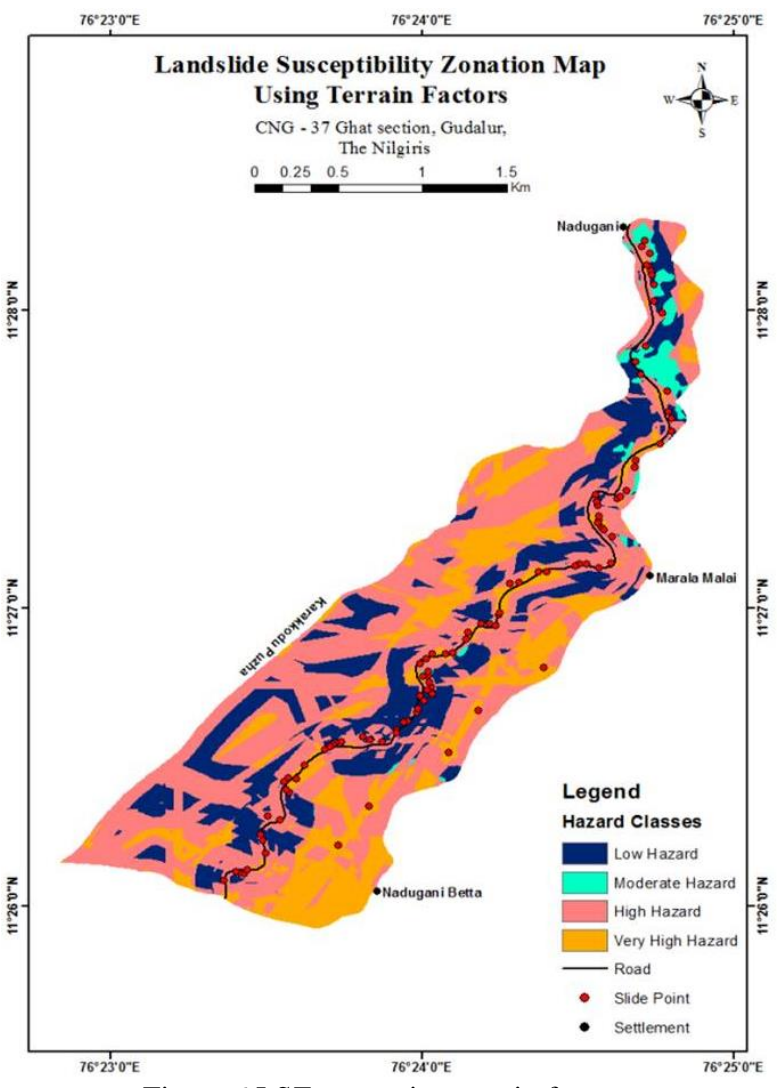

Figure 6 LSZ map using terrain factors

\section{CONCLUSION}

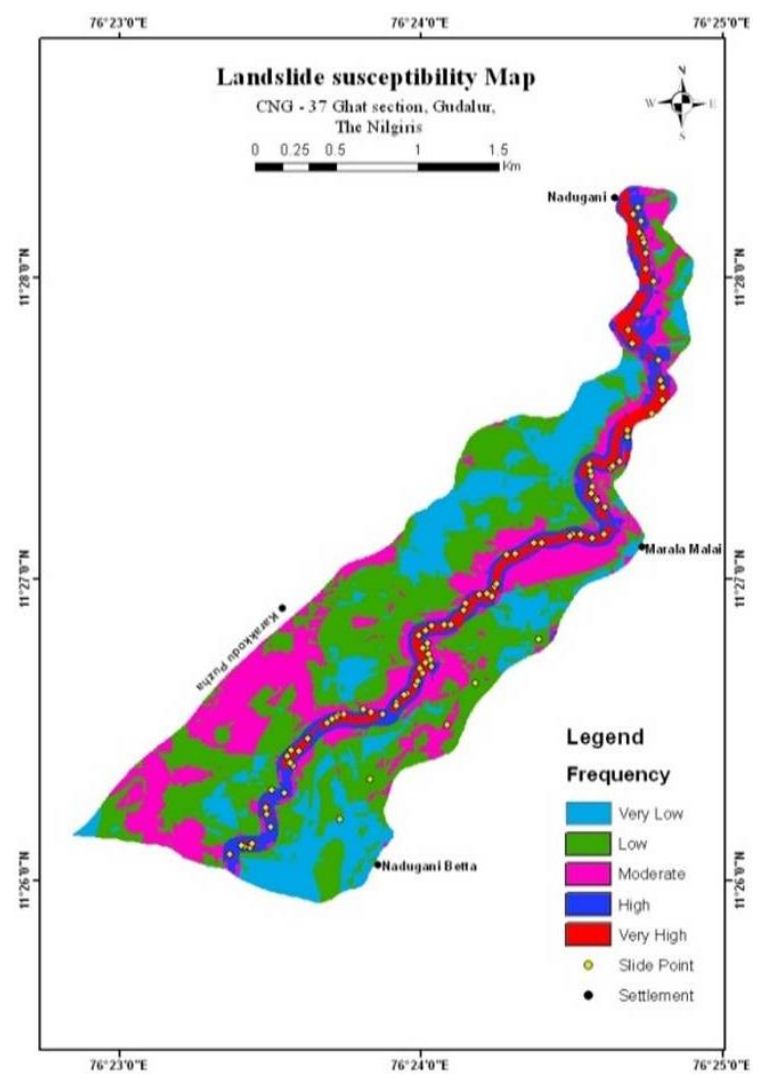

Figure LSZ map using hydrological, geological, and terrain factors

\section{REFERENCES}

Anbazhagan, S. and Saranathan, E. 2001 Structure and its impact on the drainage in part of Ponnaiyar river basin, Tamil Nadu using Remote Sensing Techniques. Journal of Indian Society of Remote Sensing, 29(4), pp.187-195.

C. Sriramkumar, E.Saranathan, G.Victor Rajamanickam and B.S.Nadage, 2006, Landslide zonation mapping - Konkan Railway, Ratnagiri Region, Maharastra., International Symposium On "Geospatial Databases for Sustainable Development, Goa, India, September 27-30, IAPRS - SIS, Vol. 36, Part 4, pp.582 - 586 .

Garrett J., 1994, Where and why artificial neural networks are applicable in civil engineering. J Comput Civil Eng 8, pp129-130.

Kannan, M., Saranathan, E., AND Anbalagan, R. 2011, Macro Landslide Hazard Zonation Mapping - Case Study from Bodi - Bodimettu Ghats Section, Theni District, Tamil Nadu - India, Journal of Indian Society of Remote Sensing, Digital Object Identifier (DOI) 10.1007/s12524-011-0112-4. 39(4), pp $485-496$.

Kannan, M., Saranathan, E., AND Anbalagan, R., 2015, Comparative analysis in GIS-based landslide hazard zonation-a case study in Bodi-Bodimettur Ghat Section, Theni District, Tamil Nadu, India, Arabian Journal of Geosciences, (DOI 10.1007/s12517-013-1259-9), 8(2), pp $691-699$.

Lee S, Ryu JH, Won JS, and Park HJ 2004, Determination and application of the weights for landslide susceptibility mapping using an artificial neural network. Eng Geol 71(3/4), pp 289-302.

Mani S, AND Saranaathan S.E., 2016, Hydrological parameters Controls Vulnerable Zones in Calicut - Nilambur - Gudalur Ghat section, Gudalur, The Nilgiris, Tamil Nadu, International Journal of ChemTech research, 9(3), pp 248 253.

Nagarajan, R., Mukherjee, A., Roy, A. and Khire, M.V., 1998, Temporal remote sensing data and GIS application in landslide hazard zonation of part of Western Ghat, India. Int. Jour. Remote Sens., 19(4), pp.573-585.

Nefeslioglu HA, Gokceoglu C, and Sonmez H., 2008, An assessment on the use of logistic regression and artificial neural networks with different sampling strategies for the preparation of landslide susceptibility maps. Eng Geol 97(3/4), pp 171-191.

Reza Talaei, 2014, Landslide susceptibility Zonation mapping using Logistic Regression and its validation in Hashtchin Region, Northwest of IRAN, Journal Geological Society of India, 84(1), pp. 68-86.

Saaty, T.L. and Vargas, L.G. 2001, Models, methods, concepts and applications of the analytic hierarchy process

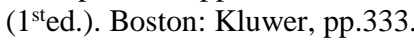


Saranaathan S.E. AND Mani S, 2016, Landslide Susceptibility Zonation mapping using Multi-criterion Analysis - CNG 37 ghat section, Nadugani, Gudalur Taluk, The Nilgiris - Using Geological Factors, International Journal of Earth Science and Engineering, 9(4) In-press.

Saranathan, E., Kannan, M AND Victor rajamanickam, G., 2012, Assessment of Landslide Hazard Zonation mapping in Kodaikkanal, Tamil Nadu, India, International Journal of Disaster Advances, 5(4), pp $42-50$.

Sonmez H, Gokceoglu C, Kayabas 1 1 A, and Nefesliog $־ l u$ HA., 2006, Estimation of rock modulus: for intact rocks with an artificial neural network and for rock masses with a new empirical equation. Int J Rock Mech Min Sci 43(2), pp 224235.
Tunusluoglu MC, Gokceoglu C, Sonmez H, and Nefeslioglu HA., 2007, An artificial neural network application to produce debris source areas of Barla, Besparmak, and Kapi Mountains (NW Taurids, Turkey. Nat Hazards Earth Syst Sci 7, pp 557-570.

Varnes, D.J., 1978Slope movement types and process, In: Landslides, analysis and control, Transportation Research Board Special Report, 176, pp 11-33.

Zorlu K, Gokceoglu C, Ocakoglu F, Nefeslioglu HA, and Acikalin S., 2008, Prediction of uniaxial compressive strength of sandstones using petrography-based models. Eng Geol 96(3-4), pp 141-158.

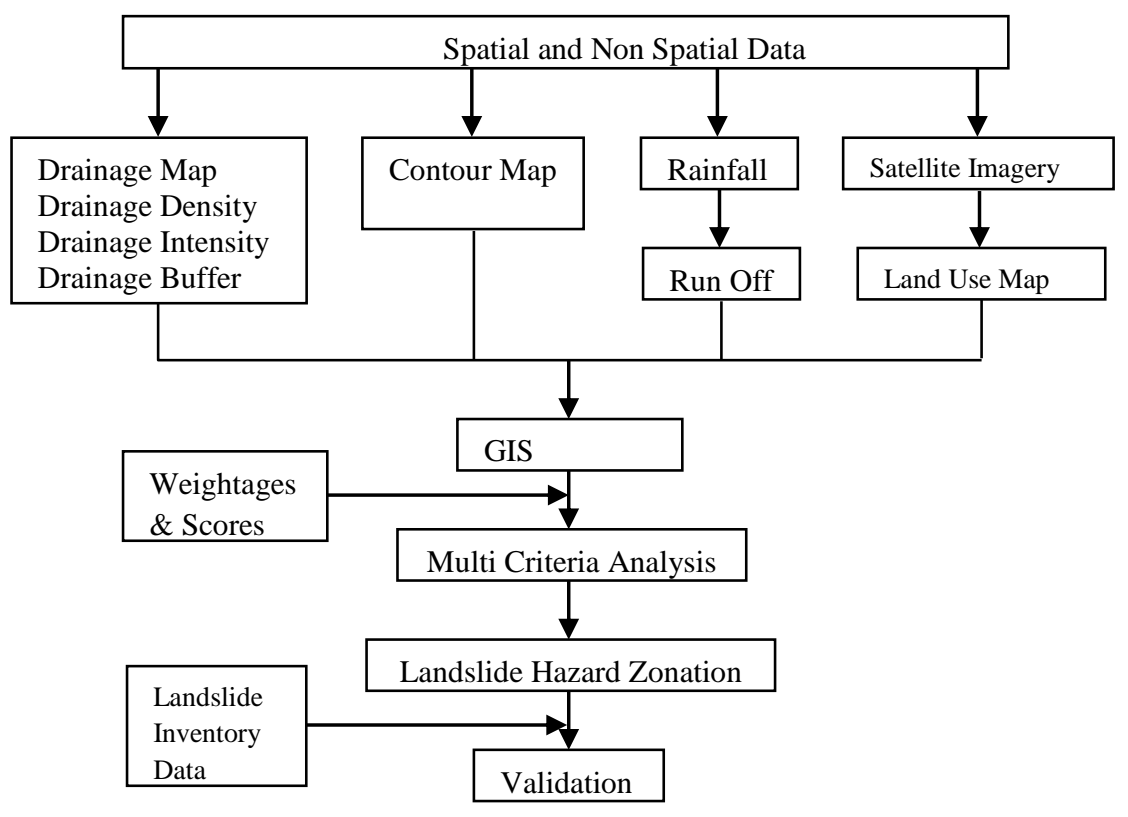

Figure 2: Hydrological Flow Chart

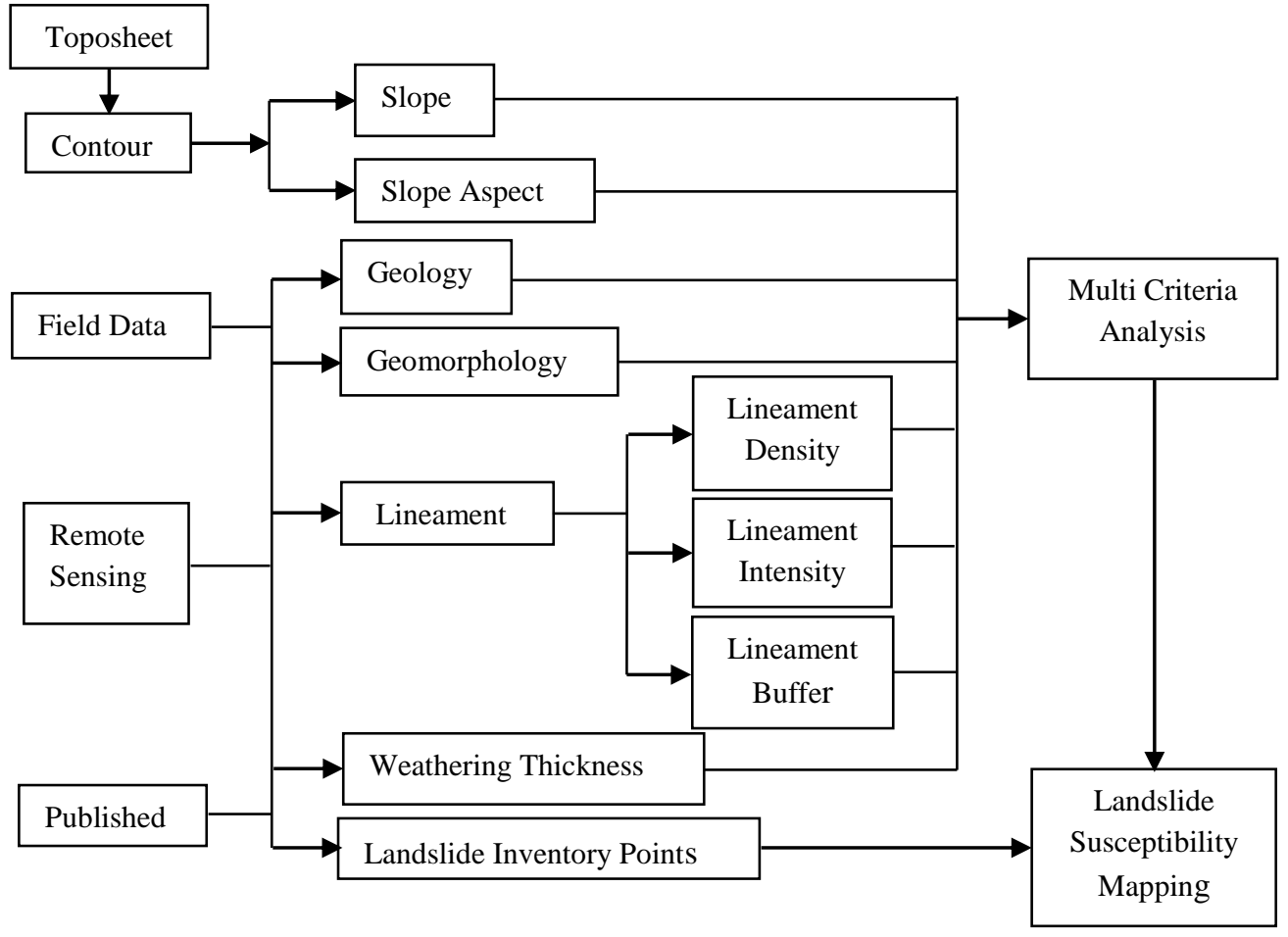

Figure 3 Geological Flow Chart 